\title{
Impact of Trichoderma-enriched Biofertilizer on the Growth and Yield of Mustard (Brassica rapa L.) and Tomato (Solanum lycopersicon Mill.)
}

\author{
Md. Manjurul Haque ${ }^{1}$, G. N. M. Ilias $^{2}$ and A. H. Molla ${ }^{1}$ \\ ${ }^{1}$ Department of Bioenvironmental Science, Faculty of Agriculture, Bangabandhu Sheikh Mujibur \\ Rahman Agricultural University, Gazipur-1706, Bangladesh \\ ${ }^{2}$ Natore Development Society (NDS), Natore and M/S RASH Agro Enterprise, Natore-6400, \\ Bangladesh \\ *Corresponding author and Email: ahmolla60@gmail.com
}

Received: 04 July $2012 \quad$ Accepted: 15 November 2012

\begin{abstract}
Biofertilizer plays a significant role in crop cultivation with reduced the chemical fertilizer use. Three Trichoderma-enriched biofertilizers were evaluated in mustard and tomato cultivation at field condition. Sole application of biofertilizers didn't show remarkable contribution but all Trichodermaenriched biofertilizers when supplemented with $\mathrm{N}$ fertilizer significantly boosted up the growth and yield of mustard and tomato. Application of 50\% $\mathrm{N}$ fertilizer along with 50\% Trichoderma-enriched biofertilizers augmented 108 and $203 \%$ yields over control both in mustard and tomato, respectively which were 81.90 and $61.82 \%$ in mustard and tomato at standard doses of Nitrogen, Phosphorus and Potassium fertilizers. The present results suggest that Trichoderma-enriched biofertilizer could save at least $50 \% \mathrm{~N}$ fertilizer uses for mustard and tomato and could reduce excessive uses of NPK for crop cultivation.
\end{abstract}

\section{Keywords: Trichoderma, biofertilizer, crop growth, yield, biomass, tomato, mustard}

\section{Introduction}

There is an agreement that among all the nutrients amendments applied to soil, N-fertilizer have by far the most important effects in terms of crop yield enhancement. There is increased emphasis on the environmental quality due to continuous use of chemical fertilizers. The integrated nutrient management i.e. combined use of chemical fertilizers with organic materials such as animal manures, crop residues, green manure and composts are alternatives and are characterized by reduced input of chemical fertilizers. Organic manures are well established to be useful in fertilization of plants due to thair beneficial effect on the physical, chemical and biological characteristics of the soil, which in turns, influence growth and increase plant production (Molla et al., 2005; Meunchang et al., 2006). In recent years, biofertilizers the products containing living cells of different types of microorganisms are also used in the integrated nutrient supply system. Biofertilizers can convert nutritionally important elements from unavailable to available form through biological processes leading to crop yields (Hegde et al., 1999). Many researchers studied the role of organic manures, which was incorporated with biofertilizer as stimulating the plant growth and yield of vegetables (Shaheen et al., 2007). Several studies have also shown that the use of compost in agriculture is beneficial to soil, crops 
and environment (Rodd et al., 2002; Rahman et al., 2006). Moreover, compost acts as a longterm reserve and slow-release sources of major nutrient like N, P and K (Sullivan et al., 2002).

Trichoderma harzianum, a filamentous fungus is used as a successful biological control agent to control different soil borne plant pathogens such as Pythium spp. Rhizoctonia solani, Fusarium spp., Sclerotium rolfsii etc (Harman et al., 2004). It was demonstrated that $T$. harzianum induced defense responses and systemic resistance in addition to control of plant pathogens (Alfano et al., 2007). Moreover, several species of Trichoderma promoted growth and development of seedlings of vegetable and non-vegetable crops (Bal and Altintas, 2006; Bal and Altintas, 2008). Furthermore, cucumber, bell pepper and strawberry yields were increased significantly by application of Trichoderma spp. (Elad et al., 2006). Efficient use of Trichoderma-enriched biofertilizer may increase yield, reduce the uses of $\mathrm{N}$ fertilizers, reduce soil borne pathogens and improve soil health. The objectives of the present study were to investigate the impact of Trichoderma-enriched biofertilizer on yield and yield contributing characters and extent of reduction of $\mathrm{N}$-fertilizers use alone or in combinations in tomato (Lycopersicon esculentum Mill.) and mustard (Brassica rapa L.) cultivation under field condition.

\section{Materials and Methods}

\subsection{Experimental site, seed sowing and seedling transplantation}

The experiments were carried out at the Agricultural Farm of the Bangabandhu Sheikh Mujibur Rahman Agricultural University (BSMRAU), Gazipur, Bangladesh during winter season (Nov. 2008 to Feb 2009). The soil of the experimental site was analyzed for $\mathrm{N}$ based on Micro-Kjeldahl method (Bremner, 1960), for $\mathrm{P}$ by description of Olsen et al., (1965) and for K based on procedure described by Jackson (1973). Mustard (variety- BARI mustard 16) seeds were sown in line on $1^{\text {st }}$ December. Conversely, for tomato (variety- Rattan) 1 month old, uniform and healthy single seedling was transplanted in each pit on $3^{\text {rd }}$ December. Seedlings of tomato were grown in raised seed bed $(5 \mathrm{~g}$ seeds were sown in seed bed of $3 \mathrm{~m} \mathrm{x} 1 \mathrm{~m}$ ) of sandy loam soil with addition of well decomposed compost $(10 \mathrm{~kg} / \mathrm{bed})$. The unit plot size for both crops was $2.5 \mathrm{~m} \times 2.0 \mathrm{~m}$ and spacing was $50 \mathrm{~cm} \times 50 \mathrm{~cm}$ for tomato. For mustard, line spacing of $30 \mathrm{~cm}$ and plant to plant distance of $4-5 \mathrm{~cm}$ were maintained after thinning.

\subsection{Source of Trichoderma-enriched biofertilizer (BioF)}

Three biofertilizers enriched with Trichoderma harzianum were used in the present experiment. These were: (a) BioF/compost (Trichodermaenriched organic compost i.e. household kitchen wastes were composted with Trichoderma harzianum); (b) BioF/pellets (T. harzianum coated wheat grains i.e. T. harzianum was allowed to grow over broken wheat grains); and (c) BioF/suspension (Broth of T. harzianum i.e. fungal spores-suspension were grown in liquid media, contained $(\mathrm{g} / \mathrm{l}) \mathrm{KNO}_{3} 1.0, \mathrm{KH}_{2} \mathrm{PO}_{4}$ 0.5, $\mathrm{MgSO}_{4} 7 \mathrm{H}_{2} \mathrm{O} 0.25$, glucose 34 , trace element $\mathrm{FeCl}_{3}$ 0.5-1.0 and $\mathrm{pH}$ of 6.5 was maintained). Five pieces of $8 \mathrm{~mm}$ sized agar block of Trichoderma inocula were taken into $500 \mathrm{ml}$ prior autoclaved $\left(15 \mathrm{~min}\right.$ at $121{ }^{\circ} \mathrm{C}$ ) aforesaid media in $1000 \mathrm{ml}$ Erlenmeyer flask from 4 days old culture grown in PDA $3.9 \%$ potato dextrose agar) media. Then the flasks were incubated at $150 \mathrm{rpm}$ in orbital shaker for 7 days at room temperature. Afterward the fungal suspension was filtered by $12.5 \mathrm{~cm}$ Whatman \# 1filter paper. The obtained fungal spores culture was used as BioF/suspension (contained 3.5-6.15 $\times 10^{6}$ spores/ml approximately).

\subsection{Fertilizer application and intercultural operations}

Fertilizers were applied as per the soil analysis results for the respective experimental field. The doses of urea, triple super phosphate (TSP) and muriate of potash (MP) were 135, 54 and 5 $\mathrm{g} / \mathrm{plot}$ respectively, for tomato. The equivalent 
doses for mustard were 83,36 and $5 \mathrm{~g} / \mathrm{plot}$. The total amount of TSP and MP and $1 / 3^{\text {rd }}$ of urea were applied at final land preparation. The remaining urea was applied in two equal splits i.e. half at 30 days after transplanting/seed sowing and half at 60 days after sowing for mustard seeds and 75 days after transplanting for tomato seedlings. Biofertilizers such as $\mathrm{BioF} /$ compost, $\mathrm{BioF} /$ pellets and $\mathrm{BioF} /$ suspension were applied @ 618 g/plot, 5 g/plant and 5 $\mathrm{ml} /$ plant, respectively. The $\mathrm{BioF} /$ compost and $\mathrm{BioF} /$ pellets were applied to the soil immediately before sowing of mustard seeds and transplanting of the tomato seedlings. In case of mustard, BioF/suspension @ $25 \mathrm{ml}$ was applied in each row at 2-3 days after seedling emergence with water by hand sprayer. On the other hand, BioF/pellets@25 g were dropped in each row before the sowing of seeds of mustard. In case of tomato, roots of the seedling were immersed in $\mathrm{BioF} /$ suspension and kept for approximately 30 $\mathrm{min}$ before transplanting. Five $\mathrm{ml}$ of $\mathrm{BioF} /$ suspension was applied in each pit immediately after the seedlings were transplanted. The intercultural operations viz. gap filling, thinning (only for mustard), weeding, stalking, pruning, irrigation etc were done as needed.

\subsection{Parameters considered for data collection}

Four tomato and 10 mustard plants were randomly selected from each plot in such a way that the border effect was avoided. Data were collected for both tomato and mustard on plant height $(\mathrm{cm})$, branches and leaves number per plant, root and shoot dry matter at 50\% flowering stage (oven dried at $70^{\circ} \mathrm{C}$ for 3 days), clusters number per plant and number of flowers per cluster counted during full bloom. In addition, in case of tomato, data were also collected for number of fruits per plant, weight of individual fruit $(\mathrm{g})$, and weight of fruits per plant $(\mathrm{kg})$ at harvest. In case of mustard, additional data were collected on number of siliqua per plant, length of siliqua $(\mathrm{cm})$, number of seeds per siliqua after harvest, seed yield per plant (g) and yield per plot (g) after cleaning and drying.

\subsection{Experimental design and statistical analysis}

Experiments were conducted in a randomized complete block design (RCBD) with three replications and eight treatments. The assigned treatments were $\mathrm{T}_{1}-$ control (without biofertilizer and chemical fertilizers), $\mathrm{T}_{2}-\mathrm{NPK}$ fertilizer, $\mathrm{T}_{3}-\mathrm{BioF} /$ compost $(618 \mathrm{~g} / \mathrm{plot}), \mathrm{T}_{4}-$ $\mathrm{BioF} /$ pellets $(5 \mathrm{~g} /$ plant for tomato and $25 \mathrm{~g} / \mathrm{row}$

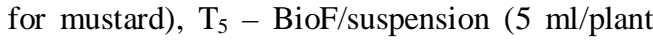
for tomato and $25 \mathrm{ml} /$ row for mustard), $\mathrm{T}_{6}-50 \%$ $\mathrm{N}$-fertilizer $+50 \%$ BioF/compost, $\mathrm{T}_{7}-50 \% \mathrm{~N}$ fertilizer $+50 \% \mathrm{BioF} /$ pellets and $\mathrm{T}_{8}-50 \% \mathrm{~N}$ fertilizer $+50 \% \mathrm{BioF} /$ suspension. Analysis of variance and comparison of means were calculated separately using a statistical package MSTAT-C (MSU, 1989). The treatment means were compared by the least significance difference (LSD) test. Based on LSD values different treatment means were separated from each other by different letters for easy interpretation.

\section{Results and Discussion}

\subsection{Impact of Trichoderma-enriched biofertilizer (BioF) on vegetative growth}

Trichoderma-enriched biofertilizer alone did not increase plant height, number of branches and number of leaves per plant in mustard compared to NPK fertilizer i.e. $T_{2}$ (Table 1). However application of Trichoderma-enriched biofertilizers along with $\mathrm{N}$-fertilizer (except $\mathrm{T}_{8}$ ) expedited those characters in mustard. The tallest plant $(76.07 \mathrm{~cm})$ was obtained in $\mathrm{T}_{2}$ treated plots, which was significantly $(P \leq 0.01)$ different from $\mathrm{T}_{1}, \mathrm{~T}_{3}, \mathrm{~T}_{4}, \mathrm{~T}_{5}$ and $\mathrm{T}_{8}$. The shortest plant $(32.97 \mathrm{~cm})$ was recorded in $\mathrm{T}_{4}$, which was identical to that in $\mathrm{T}_{5}$. As in case of plant height, almost similar observations were recorded for branch and leaf number per plant of mustard.

The impact scenario of Trichoderma-enriched biofertilizer in tomato was to some extent 
different from the mustard (Table 1). The plant height of tomato was statistically identical in all treatments except $\mathrm{T}_{5}$, which produced the lowest $(46.50 \mathrm{~cm})$ plant height. Trichoderma-enriched biofertilizer alone such as $\mathrm{T}_{3}$ and $\mathrm{T}_{4}$ treatments significantly increased the number of branches per plant in tomato but they were very similar to the treatments of $T_{2}, T_{6}$ and $T_{7}$. Alternatively, the number of leaves per plant was not increased by the sole application of Trichoderma-enriched biofertilizer such as the treatments $\mathrm{T}_{3}, \mathrm{~T}_{4}$ and $\mathrm{T}_{5}$. However, combined application (i.e. supplemented with $\mathrm{N}$ ) of Trichoderma-enriched biofertilizer such as the treatments $\mathrm{T}_{6}, \mathrm{~T}_{7}$ and $\mathrm{T}_{8}$ increased the number of leaves per plant significantly $(P \leq 0.01)$. The lowest number of leaves per plant (26.13) was observed in $T_{4}$, which was not different from $\mathrm{T}_{1}$ and $\mathrm{T}_{5}$.

The leaves number of both crops was significantly lower in sole application of biofertilizers (i.e. $\mathrm{T}_{3}, \mathrm{~T}_{4}$ and $\mathrm{T}_{5}$ ) and control. But when $\mathrm{N}$ fertilizer was supplemented with Trichoderma-enriched biofertilizers, it significantly increased all parameters of mustard but only leaf number of tomato. Moreover, the supplemented $\mathrm{N}$ fertilizer with Trichodermaenriched biofertilizers did not create any impact on plant height and branch number of tomato, except in the treatment $\mathrm{T}_{8}$. Perhaps, supplementation of $\mathrm{N}$ fertilizer enhanced the proliferation and growth of fungal microbes. The increased population of Trichoderma might play positive role to make available the plant nutrients in rhizosphere zone that increased growth and development of mustard and tomato. Plant growth stimulation by Trichoderma spp. and other microbes has been reported in several crops such as bean (Inbar et al., 1994), cucumber (Kleifeld and Chet, 1992), maize (Björkman et al., 1994), pea (Naseby et al., 2000) and tomato (Ozbay et al., 2004).

\subsection{Response of Trichoderma-enriched biofertilizer on yield contributing characters}

The sole application of Trichoderma-enriched biofertilizer (i.e. $\mathrm{T}_{3}, \mathrm{~T}_{4}$ and $\mathrm{T}_{5}$ ) in mustard resulted in the lower number of flowers, number of siliqua and length of siliqua compared to $T_{2}$ (Table 2). In case of seed number, the sole application of Trichoderma-enriched biofertilizers provided almost similar result with $\mathrm{T}_{2}$. Conversely, the numbers of flower and siliqua were significantly boosted up by supplementation of $\mathrm{N}$ fertilizer with Trichodemra-enriched biofertilizers, but the siliqua length and seed number did not respond in the same way.

In case of tomato, the supplemented $\mathrm{N}$ fertilizer with Trichoderma-enriched biofertilizers increased the fruit number and flower cluster (except $\mathrm{T}_{6}$ ) significantly compared to sole application of biofertilizers, but the results were similar to $T_{2}$ (Table 2). However, the flower number per cluster did not respond significantly by combined treatments (i.e. $\mathrm{T}_{6}-\mathrm{T}_{8}$ ) compared to sole application of biofertilizer treatments.

The poorest performance of both crops (mustard and tomato) was observed in treatment $\mathrm{T}_{5}$ but supplementation of $\mathrm{N}$ fertilizer to it i.e. treatment $\mathrm{T}_{8}$ expedited the reproductive growth and yield of tomato significantly and not of mustard (Table 2). On the contrary, the highest performance was noted in most of the parameters at $\mathrm{T}_{7}$ of both crops but poor performance was noticed in most cases at $\mathrm{T}_{4}$ of mustard. The results showed that the supplemented $\mathrm{N}$ fertilizer with biofertilizers (i.e. $50 \% \mathrm{~N}+50 \% \mathrm{BioF}$ ) significantly increased the number of flower per cluster, number of siliqua per plant of mustard and flower cluster and fruit number per plant of tomato, did not show any encouraging impact on siliqua length and seed number of mustard and flower number of tomato (Table 2). Perhaps, these characters of mustard and tomato are more genetically controlled i.e. poorly responsive. It has been reported that the strains of different Trichoderma species showed variable responses in cucumber, loofah and bitter gourd (Lo and Lin, 2002). Besides, it was reported that application of Trichoderma spp dramatically increased the number of fruits per plant in pepper and tomato grown in greenhouse than untreated control (Vinale et al., 2008). 
Table 1. Effect of Trichoderma-enriched biofertilizer (BioF) alone or in combination with chemical fertilizers on the growth of mustard and tomato

\begin{tabular}{|c|c|c|c|c|c|c|}
\hline \multirow{2}{*}{ Treatments } & \multicolumn{3}{|c|}{ Mustard } & \multicolumn{3}{|c|}{ Tomato } \\
\hline & $\begin{array}{l}\text { Plant height } \\
(\mathrm{cm})\end{array}$ & $\begin{array}{c}\text { Branch } \\
\text { (no/plant) }\end{array}$ & $\begin{array}{c}\text { Leaf } \\
\text { (no/plant) }\end{array}$ & $\begin{array}{l}\text { Plant height } \\
\text { (cm) }\end{array}$ & $\begin{array}{c}\text { Branch } \\
\text { (no/plant) }\end{array}$ & $\begin{array}{c}\text { Leaf } \\
\text { (no/plant) }\end{array}$ \\
\hline $\mathrm{T}_{1}$ (Control) & $49.07 \mathrm{~d}$ & $2.6 \mathrm{c}$ & $9.06 \mathrm{c}$ & $60.42 \mathrm{a}$ & $7.41 \mathrm{~b}$ & $27.07 \mathrm{~d}$ \\
\hline $\mathrm{T}_{2}$ (NPK fertilizers only) & 76.07 a & $5.9 \mathrm{a}$ & $25.20 \mathrm{a}$ & $64.58 \mathrm{a}$ & $7.83 \mathrm{ab}$ & $61.40 \mathrm{bc}$ \\
\hline $\mathrm{T}_{3}$ (BioF/compost) & $60.33 \mathrm{bcd}$ & $3.2 \mathrm{bc}$ & $9.73 \mathrm{c}$ & $66.00 \mathrm{a}$ & $9.25 \mathrm{ab}$ & $55.60 \mathrm{c}$ \\
\hline $\mathrm{T}_{4}(\mathrm{BioF} /$ pellets $)$ & $32.97 \mathrm{e}$ & $1.8 \mathrm{c}$ & $6.40 \mathrm{c}$ & $59.42 \mathrm{a}$ & $7.75 \mathrm{ab}$ & $26.13 \mathrm{~d}$ \\
\hline $\mathrm{T}_{5}$ (BioF/suspension) & $34.40 \mathrm{e}$ & $2.5 \mathrm{c}$ & $7.93 \mathrm{c}$ & $46.50 \mathrm{~b}$ & $4.00 \mathrm{c}$ & $29.30 \mathrm{~d}$ \\
\hline $\mathrm{T}_{6}(50 \% \mathrm{~N}+50 \%$ BioF/compost $)$ & $73.03 \mathrm{ab}$ & $5.4 \mathrm{a}$ & $21.40 \mathrm{ab}$ & $66.17 \mathrm{a}$ & $8.25 \mathrm{ab}$ & $69.73 \mathrm{ab}$ \\
\hline $\mathrm{T}_{7}(50 \% \mathrm{~N}+50 \% \mathrm{BioF} /$ pellets $)$ & $64.33 \mathrm{abc}$ & $5.6 \mathrm{a}$ & $24.97 \mathrm{a}$ & $71.17 \mathrm{a}$ & $9.92 \mathrm{a}$ & $62.67 \mathrm{bc}$ \\
\hline $\mathrm{T}_{8}(50 \% \mathrm{~N}+50 \% \mathrm{BioF} /$ suspension $)$ & $52.90 \mathrm{~cd}$ & $5.2 \mathrm{ab}$ & $13.67 \mathrm{bc}$ & $70.42 \mathrm{a}$ & $8.50 \mathrm{ab}$ & 73.77 a \\
\hline $\mathrm{CV}(\%)$ & 10.61 & 20.46 & 24.56 & 8.14 & 12.26 & 7.76 \\
\hline $\operatorname{LSD}(P \leq 0.01)$ & 14.02 & 1.97 & 8.66 & 12.24 & 2.3 & 9.39 \\
\hline
\end{tabular}

In column common letters are not significantly differed at LSD $(P \leq 0.01)$ level. 
Table 2. Effect of Trichoderma-enriched biofertilizer (BioF) alone or in combination with chemical fertilizers on yield contributing characters of mustard and tomato

\begin{tabular}{|c|c|c|c|c|c|c|c|}
\hline \multirow[b]{2}{*}{ Treatments } & \multicolumn{4}{|c|}{ Mustard } & \multicolumn{3}{|c|}{ Tomato } \\
\hline & $\begin{array}{c}\text { Flower } \\
\text { (per cluster) }\end{array}$ & $\begin{array}{c}\text { Siliqua } \\
\text { (no/plant) }\end{array}$ & $\begin{array}{c}\text { Siliqua } \\
\text { length }(\mathrm{cm})\end{array}$ & $\begin{array}{c}\text { Seed } \\
\text { (no/ siliqua) }\end{array}$ & $\begin{array}{c}\text { Flower } \\
\text { cluster (per } \\
\text { plant) }\end{array}$ & $\begin{array}{c}\text { Flower } \\
\text { (no/cluster) }\end{array}$ & $\begin{array}{c}\text { Fruit } \\
\text { (no/plant) }\end{array}$ \\
\hline $\mathrm{T}_{1}$ (Control) & $3.08 \mathrm{c}$ & $31.20 \mathrm{bc}$ & $4.36 \mathrm{c}$ & $10.53 \mathrm{c}$ & $9.83 \mathrm{~cd}$ & $5.45 \mathrm{bc}$ & $14.83 \mathrm{c}$ \\
\hline $\mathrm{T}_{2}$ (NPK fertilizers only) & $8.08 \mathrm{a}$ & $55.53 \mathrm{ab}$ & $6.21 \mathrm{a}$ & $16.20 \mathrm{ab}$ & $19.22 \mathrm{ab}$ & $7.10 \mathrm{ab}$ & $36.83 \mathrm{a}$ \\
\hline $\mathrm{T}_{3}(\mathrm{BioF} /$ compost $)$ & $5.25 \mathrm{bc}$ & $32.80 \mathrm{bc}$ & $5.82 \mathrm{ab}$ & $14.27 \mathrm{abc}$ & $21.67 \mathrm{a}$ & $7.00 \mathrm{ab}$ & $25.60 \mathrm{~b}$ \\
\hline $\mathrm{T}_{4}$ (BioF/pellets) & $3.08 \mathrm{c}$ & $29.20 \mathrm{bc}$ & $4.71 \mathrm{bc}$ & $15.67 \mathrm{abc}$ & $13.33 \mathrm{bc}$ & $6.17 \mathrm{abc}$ & $20.50 \mathrm{bc}$ \\
\hline $\mathrm{T}_{5}(\mathrm{BioF} /$ suspension $)$ & $5.58 \mathrm{~b}$ & $24.07 \mathrm{c}$ & $4.56 \mathrm{bc}$ & $12.40 \mathrm{bc}$ & $4.75 \mathrm{~d}$ & $4.67 \mathrm{c}$ & $13.70 \mathrm{c}$ \\
\hline $\mathrm{T}_{6}(50 \% \mathrm{~N}+50 \%$ BioF/compost $)$ & $5.83 \mathrm{ab}$ & $55.80 \mathrm{ab}$ & $5.54 \mathrm{abc}$ & $16.47 \mathrm{ab}$ & $16.42 \mathrm{abc}$ & $6.45 \mathrm{ab}$ & $35.97 \mathrm{a}$ \\
\hline $\mathrm{T}_{7}(50 \% \mathrm{~N}+50 \% \mathrm{BioF} /$ pellets $)$ & $6.08 \mathrm{ab}$ & $62.40 \mathrm{a}$ & $5.80 \mathrm{ab}$ & $19.07 \mathrm{a}$ & $21.00 \mathrm{a}$ & $7.75 \mathrm{a}$ & $41.03 \mathrm{a}$ \\
\hline $\mathrm{T}_{8}(50 \% \mathrm{~N}+50 \% \mathrm{BioF} /$ suspension $)$ & $6.25 \mathrm{ab}$ & $43.07 \mathrm{abc}$ & $5.06 \mathrm{abc}$ & $13.00 \mathrm{bc}$ & $18.73 \mathrm{ab}$ & $6.33 \mathrm{abc}$ & $39.43 \mathrm{a}$ \\
\hline $\mathrm{CV}(\%)$ & 18.85 & 29.62 & 10.80 & 14.70 & 17.97 & 11.67 & 13.04 \\
\hline $\operatorname{LSD}(P \leq 0.01)$ & 2.43 & 29.50 & 1.35 & 5.15 & 6.69 & 1.76 & 8.86 \\
\hline
\end{tabular}

In column common letters are not significantly differed at $\operatorname{LSD}(P \leq 0.01)$ level. 


\subsection{Impact of Trichoderma-enriched biofertilizers on yield of mustard and tomato}

The highest seed yield (1.577 g) per plant of mustard was found in $\mathrm{T}_{6}$, which was followed by $\mathrm{T}_{2}, \mathrm{~T}_{3}, \mathrm{~T}_{5}, \mathrm{~T}_{7}$ and $\mathrm{T}_{8}$ treatments (Table 3). Similarly, the seed yield per plot of mustard was also recorded the highest in $\mathrm{T}_{6}$, which was similar to $\mathrm{T}_{2}, \mathrm{~T}_{3}, \mathrm{~T}_{5}$ and $\mathrm{T}_{7}$. The highest yield promotion $(108.36 \%)$ was attained in treatment $\mathrm{T}_{6}$ and the second highest was 81.90 in $\mathrm{T}_{2}$ treatment (Table 3). These results implied that the treatment $\mathrm{T}_{6}$ could save at least $50 \%$ of $\mathrm{N}$ fertilizer.

Fruit yield of tomato per plant varied significantly among the treatments (Table 3). The maximum individual fruit weight was obtained in $\mathrm{T}_{8}$, which did not differ significantly from treatment $T_{7}$ but was identical to $T_{2}$. The minimum individual fruit weight was recorded in control treatment $\left(\mathrm{T}_{1}\right)$. The highest fruit yield per plant $(1.67 \mathrm{~kg})$ was recorded in $\mathrm{T}_{8}$, which was significantly $(P \leq 0.01)$ different from with rest of the treatments. $\mathrm{N}$ fertilizer supplemented treatments $T_{6}$ and $T_{7}$ gene the second highest yield, which was significantly lower than the $T_{8}$ treatment, but significantly higher than the other treatments including $T_{2}$. The lowest fruit yield per plant $(0.55 \mathrm{~kg})$ was found in the control treatment. Yield increase of $203 \%$ was recorded in the treatment $\mathrm{T}_{8}$, whereas 125 and $156 \%$ yield increase were observed in $\mathrm{T}_{6}$ and $\mathrm{T}_{7}$ treatments, respectively over control. The yield increase of $61.82 \%$ was observed in $\mathrm{T}_{2}$ over control However, 56, 31 and 9\% were observed in sole biofertilizers i.e. $\mathrm{T}_{3}, \mathrm{~T}_{4}$ and $\mathrm{T}_{5}$ treatments, respectively over the control. The yields were significantly influenced by the combined treatments i.e. $\mathrm{T}_{6-} \mathrm{T}_{8}$ by supplementation of $\mathrm{N}$ fertilizer to the biofertilizers. These results implied that yield of tomato was significantly increased when Trichoderma-enriched biofertilizers were combined with chemical $\mathrm{N}$ fertilizer (Table 3). The combined treatment gave significantly higher yield of tomato than the treatment $T_{2}$ i.e. standard dose of NPK fertilizer.
Generally, the $\mathrm{NO}_{3}{ }^{-}$form of $\mathrm{N}$ fertilizer couldn't retain long time to the rhizosphere zone of plants and therefore, split application of $\mathrm{N}$ fertilizer was suggested at different stages of crop growth. Conversely, the organic amendments and microbes played a roles to slow by release the plant nutrients. The microbial population in soil releases some exudates (organic substances), increases nutrient uptake through enhanced root growth or promotes availability of necessary nutrients and solubilize a number of poorly soluble nutrients, such as $\mathrm{Mn}^{4+}, \mathrm{Fe}^{3+}$ and $\mathrm{Cu}^{2+}$ etc (Kleifeld and Chet, 1992; Altomare et al., 1999). Therefore, in present study the combined treatments enhanced efficient utilization of nutrients than the others which expedited crop growth and yield.

\subsection{Impact on dry matter production}

Influence of different forms of Trichodermaenriched biofertilizers alone or in combination with $\mathrm{N}$ fertilizer on dry matter production of mustard was also noticed in the present study (Table 4). The highest root $(0.66 \mathrm{~g} / \mathrm{plant})$ and shoot $(6.83 \mathrm{~g} /$ plant $)$ dry matter weight of mustard was found in $\mathrm{T}_{6}$ treatment. The lowest root dry matter $(0.11 \mathrm{~g})$ was recorded in $\mathrm{T}_{1}$, which was followed by $\mathrm{T}_{4}$ treatment. Shoot dry weight followed the similar trend as root dry weight. There clearly illustrated that dry matter production was boosted up by the supplementation of partial $\mathrm{N}$ fertilizer to each biofertilizer application. The scenario of root and shoot dry weight of tomato also followed the similar profile as mustard (Table 4). Similar trend of results was noticed in corn shoot dry weight using $T$. harzianum (Björkman et al., 1994). Increased root dry weight by application of Trichoderma-enriched biofertilizer might be one of the important factors for enhancing growth and yield of mustard and tomato. Furthermore, the increased root biomass could increase the chance for acquisition of nutrients by exploitation of more volume of soils. 
Table 3. Effect of Trichoderma-enriched biofertilizer (BioF) alone or in combination with chemical fertilizers on yield of mustard and tomato

\begin{tabular}{|c|c|c|c|c|c|c|}
\hline \multirow{2}{*}{ Treatments } & \multicolumn{3}{|c|}{ Mustard } & \multicolumn{3}{|c|}{ Tomato } \\
\hline & $\begin{array}{l}\text { Seed yield } \\
\text { (g/plant) }\end{array}$ & $\begin{array}{l}\text { Yield } \\
\text { (g/plot) }\end{array}$ & $\begin{array}{l}\text { Percent yield } \\
\text { increased }\end{array}$ & $\begin{array}{l}\text { Individual fruit } \\
\text { wt.(g) }\end{array}$ & $\begin{array}{l}\text { Fruit yield } \\
\text { (kg/plant) }\end{array}$ & $\begin{array}{l}\text { Percent yield } \\
\text { increased }\end{array}$ \\
\hline $\mathrm{T}_{1}($ Control $)$ & $0.529 \mathrm{~b}$ & $69.16 \mathrm{~cd}$ & - & $62.27 \mathrm{~d}$ & $0.55 \mathrm{~d}$ & - \\
\hline $\mathrm{T}_{2}$ (NPK fertilizers only) & $1.303 \mathrm{ab}$ & $125.80 \mathrm{ab}$ & 81.90 & $82.00 \mathrm{ab}$ & $0.89 \mathrm{c}$ & 61.82 \\
\hline $\mathrm{T}_{3}$ (BioF/compost) & $0.913 \mathrm{ab}$ & $99.05 \mathrm{abc}$ & 43.21 & $71.87 \mathrm{c}$ & $0.86 \mathrm{c}$ & 56.36 \\
\hline $\mathrm{T}_{4}$ (BioF/pellets) & $0.533 \mathrm{~b}$ & $71.36 \mathrm{~cd}$ & 3.19 & $71.03 \mathrm{c}$ & $0.72 \mathrm{~cd}$ & 30.90 \\
\hline $\mathrm{T}_{5}$ (BioF/suspension) & $1.213 \mathrm{ab}$ & $101.54 \mathrm{abc}$ & 46.82 & $72.50 \mathrm{c}$ & $0.60 \mathrm{~d}$ & 9.09 \\
\hline $\mathrm{T}_{6}(50 \% \mathrm{~N}+50 \% \mathrm{BioF} /$ compost $)$ & $1.577 \mathrm{a}$ & $144.1 \mathrm{a}$ & 108.36 & $74.43 \mathrm{bc}$ & $1.24 \mathrm{~b}$ & 125.45 \\
\hline $\mathrm{T}_{7}(50 \% \mathrm{~N}+50 \%$ BioF/pellets) & $1.280 \mathrm{ab}$ & $101.1 \mathrm{abc}$ & 46.18 & $86.57 \mathrm{a}$ & $1.41 \mathrm{~b}$ & 156.36 \\
\hline $\mathrm{T}_{8}(50 \% \mathrm{~N}+50 \% \mathrm{BioF} /$ suspension $)$ & $0.773 \mathrm{ab}$ & $79.27 \mathrm{bcd}$ & 14.18 & $87.17 \mathrm{a}$ & $1.67 \mathrm{a}$ & 203.63 \\
\hline $\mathrm{CV}(\%)$ & 33.98 & 24.04 & - & 4.49 & 9.0 & - \\
\hline $\operatorname{LSD}(P \leq 0.01)$ & 0.88 & 51.16 & - & 8.14 & 0.21 & - \\
\hline
\end{tabular}

In column common letters are not significantly differed at LSD $(P \leq 0.01)$ level. 
Table 4. Dry matter production of mustard and tomato as influenced by Trichoderma-enriched bioferlizer (BioF) alone or in combination with chemical fertilizers

\begin{tabular}{|c|c|c|c|c|}
\hline \multirow[t]{2}{*}{ Treatments } & \multicolumn{2}{|c|}{ Mustard } & \multicolumn{2}{|c|}{ Tomato } \\
\hline & Root weight/plant (g) & Shoot weight/plant (g) & Root weight/plant (g) & Shoot weight/plant (g) \\
\hline $\mathrm{T}_{1}$ (Control) & $0.11 \mathrm{e}$ & $2.09 \mathrm{e}$ & $0.11 \mathrm{~g}$ & $2.07 \mathrm{~d}$ \\
\hline $\mathrm{T}_{2}$ (NPK fertilizers only) & $0.34 \mathrm{c}$ & $5.02 \mathrm{c}$ & $0.38 \mathrm{~d}$ & $4.36 \mathrm{c}$ \\
\hline $\mathrm{T}_{3}$ (BioF/compost) & $0.27 \mathrm{~cd}$ & $3.68 \mathrm{~d}$ & $0.32 \mathrm{de}$ & $3.96 \mathrm{c}$ \\
\hline $\mathrm{T}_{4}$ (BioF/pellets) & $0.14 \mathrm{e}$ & $2.45 \mathrm{e}$ & $0.28 \mathrm{ef}$ & $2.40 \mathrm{~d}$ \\
\hline $\mathrm{T}_{5}(\mathrm{BioF} /$ suspension $)$ & $0.19 \mathrm{de}$ & $2.05 \mathrm{e}$ & $0.21 \mathrm{f}$ & $2.54 \mathrm{~d}$ \\
\hline $\mathrm{T}_{6}(50 \% \mathrm{~N}+50 \%$ BioF/compost $)$ & $0.66 \mathrm{a}$ & $6.83 \mathrm{a}$ & $0.69 \mathrm{a}$ & $6.57 \mathrm{a}$ \\
\hline $\mathrm{T}_{7}(50 \% \mathrm{~N}+50 \%$ BioF/pellets $)$ & $0.58 \mathrm{ab}$ & $5.70 \mathrm{~b}$ & $0.59 \mathrm{~b}$ & $5.42 \mathrm{~b}$ \\
\hline $\mathrm{T}_{8}(50 \% \mathrm{~N}+50 \% \mathrm{BioF} /$ suspension $)$ & $0.54 \mathrm{~b}$ & $5.26 \mathrm{bc}$ & $0.48 \mathrm{c}$ & $5.08 \mathrm{~b}$ \\
\hline $\mathrm{CV}(\%)$ & 11.78 & 5.86 & 7.86 & 5.37 \\
\hline $\operatorname{LSD}(P \leq 0.01)$ & 0.106 & 0.579 & 0.075 & 0.517 \\
\hline
\end{tabular}

In column common letters are not significantly differed at LSD $(P \leq 0.01)$ level. 
In general, the application of biofertilizers in different form enhanced dry matter production of mustard and tomato. The dry matter production was boosted up while biofertilizers were supplemented with $\mathrm{N}$ fertilizer. The growth, maintaining population and adaptation of microbes in rhizosphere zones are determined to some extent by the root exudations. The impact of compost on superior plant growth was most likely due to increase in $\mathrm{N}$ availability as well as its slow and steady release in growing media (Erhart et al., 2005). Moreover, the compost treated plants might obtain some additional plant nutrients for growth and development (Meunchang et al., 2006).

\section{Conclusions}

In the present study, it was clearly observed that the Trichoderma-enriched biofertilizer had positive impact on growth and yield of mustard and tomato. The impact of Trichodermaenriched biofertilizer accelerated when it was supplemented with $\mathrm{N}$ fertilizer application. Superior and significant growth, yield and dry matter production were increased by supplementation of $\mathrm{N}$ fertilizer with Trichoderma-enriched biofertilizer. Maximum of $108.36 \%$ yield increase of mustard over control was recorded in $\mathrm{T}_{6}$ i.e. combined treatment, which was $92 \%$ of control. Similarly, the maximum $203.63 \%$ yield increase over control of tomato was noticed in $\mathrm{T}_{8}$, which was $61.82 \%$ in $\mathrm{T}_{2}$. The responses of both crops to biofertilizers were not alike. It may be concluded that application of Trichoderma-enriched biofertilizer along with $\mathrm{N}$ fertilizer could save at least $50 \% \mathrm{~N}$ fertilizer giving higher yields in tomato and mustard compared to $\mathrm{T}_{2}$ (NPK treatment). Undoubtedly, there is a prospective and potential of Trichoderma contained biofertilizer in crop cultivation to achieve attractive yield and reducing $\mathrm{N}$-fertilizer application.

\section{Acknowledgement}

The authors are grateful to Mr. Altaf Hossain, Chairman, Natore Development Society (NDS), and M/S Ismotara Begum, Proprietor, M/S RASA Agro-Enterprise, Natore, Bangladesh for providing three types of Trichoderma-enriched biofertilizers.

\section{References}

Alfano, G., Lewis Ivey, M. L., Cakir, C., Bos, J. I. B., Miller, S. A., Madden, L. V., Kamoun, S. and Hoitink, H. A. J. 2007. Systemic modulation of gene expression in tomato by Trichoderma hamatum 382. Phytopathology, 97: 429-437.

Altomare, C., Norvell, W. A., Bjorkman, T. and Harman, G. E. 1999. Solubilization of phosphates and micronutrients by the plant-growth-promoting and biocontrol fungus Trichoderma harzianum Rifai 1295-22. Applied and Environmental Microbiology, 65: 2926-2933.

Bal, U. and Altintas, S. 2006. A positive side effect from Trichoderma harzianum, the biological control agent: Increased yield in vegetable crops. Journal of Environmental Protection and Ecology, 7: 383-387.

Bal, U. and Altintas, S. 2008. Effects of Trichoderma harzianum on lettuce in protected cultivation. Journal Central European Agriculture, 1: 63-70.

Björkman, T., Price, H. C., Harman, G. E., Ballerstein, J. and Nielsen, P. 1994. Improved performance of shrunken 2 sweet corn using Trichoderma harzianum as a bioprotectant. Hort Science, 29: 471.

Bremner, J. M. 1960. Determination of nitrogen in soil by the Kjeldahl method. Journal of Agricultural Science, 55:11-31.

Elad, Y., Chet, I. and Henis, Y. 2006. Biological control of Rhizoctonia solani in strawberry fields by Trichoderma harzianum. Plant and Soil, 60: 245-254.

Erhart, E., W. Hartl, W. and Putz, B. 2005. Biowaste compost affects yield, nitrogen supply during the vegetation period and 
crop quality of agricultural crops. European Journal of Agronomy, 23: 305315.

Harman, G. E., Howell, C. R., Viterbo, A., Chet, I. and Lorito, M. 2004. Trichoderma species-opportunistic, avirulent plant symbionts. Nature Reviews (Microbiology), 2: 43-56.

Hegde, D. M., Dwived, B. S. and Sudhakara, S. N. 1999. Biofertilizers for cereal production in India-a review. Indian Journal of Agriculture Science, 69: 73-83.

Inbar, J., Abramsky, M., Cohen, D. and Chet, I. 1994. Plant growth enhancement and disease control by Trichoderma harzianum in vegetable seedlings grown under commercial conditions. European Journal of Plant Pathology, 100: 337-346.

Jackson, M. L. 1973. Soil chemical analysis. Prentice Hall of India Pvt. Ltd. New Delhi, 498 p.

Kleifeld, O. and Chet. I. 1992. Trichoderma harzianum-interaction with plants and effect on growth response. Plant and Soil, 144: $267-272$.

Lo C-T. and Lin, C-Y. 2002. Screening strains of Trichoderma spp. for plant growth enhancement in Taiwan. Plant Pathology Bulletin, 11: 215-220.

Meunchang, S., Panichsakpatana, S. and Weaver, R. W. 2006. Tomato growth in soil amended with sugar mill by products compost. Plant and Soil, 280: 171-176.

Molla, A. H., Fakhru'l-Razi, A., Hanafi, M. M. and Alam, M. Z. 2005. Compost produced by solid state bioconversion of biosolids: a potential source for plant growth and environmental friendly disposal. Communications in Soil Science and Plant Analysis, 36: 1435-1447.

MSU (Michigan State University), 1989. The user's guide to MSTAT-C of Michigan State University, Lansing MI. 1989.
Naseby, D. C., Pascual, J. A. and Lynch, J. M. 2000. Effect of biocontrol strains of Trichoderma on plant growth, Pythium ultimum population, soil microbial communities and soil enzyme activities. Journal of Applied Microbiology, 88:161169.

Olsen, S. R., Cole, C. V., Watanabe, F. S. and Dean, L. A. 1965. Estimation of available phosphorous in soils by extraction with sodium bicarbonate $\left(\mathrm{NaHCO}_{3}\right)$ USDA Circ., 393 p.

Ozbay, N., Newman, S. E. and Brown, W. M. 2004. The effect of the Trichoderma strains on the growth of tomato seedlings. Acta Horticulture, 635: 131-135.

Rahman, K. M., Molla, A. H. and Rahman, M. A. 2006. Feasibility of sustainable recycling of municipal solid waste as organic fertilizer for plant growth and development. The Agriculturists, 4: 7-14.

Rodd, V., Warman, P. R., Hickelton, P. and Webb, K. 2002. Comparison of N fertilizer, source-separated municipal solid waste compost and semi-solid beef manure on the nutrient concentration in boot-stage barley and wheat tissue. Canadian Journal of Soil Science, 82: 33.

Shaheen, A. M., Fatema, A. R. and Singer, S. M. 2007. Growing onion without chemical fertilization. Research Journal of Agriculture and Biological Sciences, 3 (2): 95-104.

Sullivan, D. M., Bary, A. I., Thomas, D. R., Fransen, S. C. and Cogger, C. G. 2002. Food waste compost effects on fertilizer nitrogen deficiency, available nitrogen and tall fescue yield. Soil Science Society of American Journal, 66:154-161.

Vinale, F., Sivasithamparam, K., Ghisalberti, E. L. Marra, R. Woo, S. L. and Lorito, M. 2008. Trichoderma-plant-pathogen interactions. Soil Biology and Biochemistry, 40:1-10. 